UDC 811.161.2-38'276.6:001

DOI https://doi.org/10.24919/2663-6042.16.2021.6

\title{
THE CATEGORY OF EXPRESSIVENESS IN SCIENTIFIC LITERATURE
}

\author{
Diadiura H. M., Kolesnyk D. M., Kuhareva-Rozhko V. I. \\ Cherkassy State Technological University
}

\begin{abstract}
The following article analyzes the category of expressiveness and its components: emotionality and imagery in scientific texts. The concepts of emotiveness and emotionogenecity are determined: emotionality is a characteristic of personality, his/her condition, qualities and level of his/her emotional sphere. Emotiveness is a linguistic characteristic of the text as a set of language units, capable of causing an emotional effect or to evoke appropriate emotions in the mind of a recipient. It is determined that relevant signs for the category of expressiveness are the presence of the addressee, the degree of influence, intensity and manifestation of language, whereas the concept of emotionality focuses upon psycho-emotional state of the addressee. The functioning of figurative means of expressiveness is studied and described in both natural and technical texts. The illustrative examples that showcase the most commonly used figurative means, specifically comparisons, analogies and metaphors are given and analyzed in the article. Comparisons are the most common figure in the scientific sphere because it is one of the forms of logical thinking. Scientists often resort to the creation of visual images in their imagination when they try to discover a certain phenomenon of reality, because visual images are the most vivid and expressive. It is stated that the figurative elements of scientific style determine the formation of a figurative context. It is proven that perception of the unit as an image or non-image depends on the speakers and on the features of the communicative process. It is justified that figurative vocabulary and expressive constructions are used in the scientific literature, but the frequency of use varies depending on the genre, purpose, readers, personality of the author, subject of presentation and others extralinguistic factors. Showcased and proven is the role of expressiveness as a means of scientific knowledge. It is concluded that figurative means are characteristic for scientific language, though scientific expressiveness in particular differs from expressiveness in other styles, for example, if the expressiveness of artistic language reveals itself in the highest degree of imagery, then the scientific expressiveness lies in the evidence, concretization of opinions, the logic of statements, strengthening the argumentation of author's reasoning, activation of reader's attention.
\end{abstract}

Key words: category of expressiveness, scientific expressiveness, emotionality, emotiveness, imagery, scientific text, means of expressiveness of scientific text, figurative means, metaphor, comparison, analogy.

\begin{abstract}
Дядюра Г. М., Колесник Д. М., Кухарєва-Рожко В. І. Категорія експресивності в науковій літературі. У статті проаналізовано категорію експресивності в наукових текстах. Виокремлено основні поняття категорії експресивності, зокрема емоційність, яку витлумачено як характеристику особистості, ї̈ стану, якостей та рівня ії емоційної сфери, і емотивність як лінгвістичну характеристику тексту, щуо становить сукупність мовних одиниць, здатних породжувати емоційний ефект, тобто викликати в реципієнта відповідні емочії. Визначено, що для категорії експресивності релевантними ознаками є наявність адресата, ступінь впливу, інтенсивність та прояв у мові, а для поняття емоційності- психоемоційний стан адресанта. Досліджено й описано функиіонування образних засобів експресивності в природничих і технічних текстах. Засвідчено, щчо найбільш вживаними образними засобами є порівняння, аналогії та метафори. Порівняння, зокрема, є найпоширенішим у науковій сфері образним засобом, оскільки воно становить одну з форм логічного мислення. Зауважено, щчо з метою з'ясувати якесь явище дійсності науковиі нерідко вдаються до створення в уяві візуальних образів, оскільки саме зорові образи є найбільш яскравими й виразними. Виявлено, щзо образні елементи наукового стилю зумовлюють утворення образного контексту. Сприймання одиниці як образу чи не-образу залежить від мовців і від особливостей перебігу комунікативного процесу. Звідси обтрунтовано, щзо образна лексика та експресивні конструкиї вживаються в науковій літературі, але частотність використання градується залежно від жанру, призначення, читаџької аудиторії, індивідуальності автора, предмету викладу та інших позамовних чинників. Підсумовано, щзо експресивність як образний засіб, характерний для наукової мови, відрізняється від експресивності в інших стилях: якщо експресивність художньої мови полягає в найвищьому ступені образності, то наукової - в доказовості, конкретизації думок, логічності тверджень, посиленні аргументованості міркувань автора, активізації уваги читача.
\end{abstract}

Ключові слова: категорія експресивності, наукова експресивність, емоційність, емотивність, емоціогенність, образність, науковий текст, засоби експресивності наукового тексту, образні засоби, метафора, порівняння, аналогія.

Defining the problem and argumentation of the topicality of the consideration. Today, the study of the category of expressiveness in both domestic and foreign linguistics is given close attention to, as there are different views on the category of expressiveness in the scientific literature, the diversity of which shows that this problem has not found its unanimous and final solution. In the field of linguistics there is an active rethinking of traditional views on various linguistic phenomena, in particular, there is a large number of studies of the category of expressiveness and ways of expressing it in texts of different styles. Some researchers believe that 
the use of emotionally colored vocabulary slows down the perception of scientific information and hinders the development of scientific thought, while a number of scientific investigations (N. Arutyunova, M. Kozhina, N. Nepiyvoda, N. Razinkina, N. Lukyanova) show a beneficial effect of the usage of expressiveness in scientific texts. Their scientific works actualize the need for in-depth research on the means of expressiveness of scientific texts.

Analysis of recent research and publications. Recognition of the expressiveness of scientific texts is found in modern linguistic literature, particularly in the works of foreign and domestic scholars: M. Kozhina [5; $6 ; 7 ; 8]$, N. Razinkina [11], N. Valgina [13], N. Boyko [2], N. Nepiyvoda [10] and others. The most discussed among linguists is the relationship between the categories of expressiveness and emotionality. E. GalkinaFedoruk was the first to try to properly distinguish expressiveness and emotionality in language on the basis of differences in their tasks. She also proved the autonomous functioning of expressive and emotional elements. It is the distinction between the concepts of expressiveness and emotionality and the denial of their identity that give reason for asserting the existence of expression in scientific speech.

The purpose of the study is to analyze the category of expressiveness in the scientific literature and to establish links between it and other related concepts, such as emotionality and imagery and on the bases of natural and technical texts study to explore the linguistic means of expression.

The outline of the main research material. Expressiveness is a complex linguistic category that exists in different styles of speech. Analysis of different scientific studies concerning the category of expressiveness makes it possible to say that the category of expressiveness is one of the characteristic features of scientific presentation. It differs from the expressiveness in other styles. Expressiveness is understood as a system of language means that allows to convey the content and author's attitude as clearly as possible, and as a result to strengthen the influence on the emotional, intellectual and volitional sphere of the recipient. The general expressiveness of the text is the result of the realization of such qualities as emotionality, evaluability, imagery, intensity, stylistic labeling, structural and compositional features of the text. These functioning properties present an organic unity. The expressiveness of the text is one of the most important conditions for understanding its pragmatic function [12, 41]. Moreover, the pragmatics of the text is manifested in the fact that it affects the recipient, and contains implicit information about its author and the sphere of communication. The purpose of the text, its structure, selection of language tools is determined by the author as a language personality, his/ her individual worldview, the system of his/her values. This is why expressiveness is a constant and traditional characteristic of works of art. However, "the desire to achieve maximum expressiveness of the text often becomes a motive for language creativity not only for authors of fiction, but also of other texts" [12, 52].

$\mathrm{N}$. Boyko believes that expressiveness is a semanticstylistic super category, which is manifested in the semantic model of the word through individual components that are part of the denotative, connotative or figurative macro component and which can be identified and analyzed only in connection with them $[2,30]$.

One of the main components of the concept of expressiveness is the concept of emotionality. But in addition to this concept, there are also the concepts of emotiveness and emotionogenecity: emotionality - a psychological characteristic of the individual, his condition, qualities and level of his emotional sphere. Emotiveness is a linguistic characteristic of the text (or lexicon) as a set of language units that can cause an emotional effect, such as evoking appropriate emotions within the mind of a recipient. It is necessary to differentiate the concepts of "emotionality" and "emotionogenecity". Any content of the text is potentially emotionogenic, because there will always be a recipient for whom this content will be personally significant. In this sense, the emotionogenic effect can occur regardless of the specifics of language means by which the content is transmitted, because in this case it depends only on the content and personality of the recipient $[12,61]$. Any text can potentially evoke emotions, even when the text itself is not always emotional. Researchers also note the fact noticed by K. Galkina-Fedoruk that all emotional means of speech are expressive, but not vice versa $[12,62]$.

Expressiveness is formed during the generation of the text: the author selects such language figures that contribute to the main communicative goal and the impact on the recipient. Emotional mechanisms are of great value here, because without emotions the motivation of human behavior is not formed, in particular the motivation of speech actions. The choice of expressive means to achieve the communicative goal also depends on the motive. The greater the personal significance of the goal, the more intense is the involvement of expressive means, because with every influence on the recipient the author increases the probability of achieving the goal. Potential recipient is always taken into the account to predict which language figures will have the greatest impact on him/her [12, 64].

Thus, the driving forces of the expressiveness of the text are the motives of the author, his/her communicative purpose, the image of the recipient, the author's attitude to the displayed objects and to the linguistic means that he/she chooses to achieve the goal. Expressiveness is implemented with the help of emotionality, evaluation, imagery, structural and compositional means $[12,66]$. At the same time, as already noted, expressiveness and emotionality (emotionality, emotionogenecity) in artistic and scientific works have different functional purposes.

Expressiveness correlates with the category of beauty, serving as an aesthetic feature of speech. "It would seem," says N. Nepiyvoda, that the fulfillment of aesthetic requirements should not apply to the scientific style, which has traditionally developed as devoid of emotions (especially with regard to scientific and technical texts). "However, the category of beauty covers not only works of fiction as a kind of art. A scientific work can also be beautiful - intellectually beautiful. The aesthetic value of scientific works lies primarily in the clarity, logic, harmony of 
the transmitted ideas. Scientific texts that have a clear meaning fascinate the specialist, give him a sense of aesthetic pleasure" [10, 216-217].

The study of emotional qualities of scientific prose is important because, according to N. Razinkina, human thinking is the unity of logical and sensory cognition of reality $[11,38]$. M. Kozhina has the same opinion: "only "machine thinking" and "machine language" can be "purely" logical, absolutely generalized-abstract (behaviorist understanding of thinking and language), while human thinking and natural language, and in particular scientific style, are characterized by other obligatory, though "concomitant", but important features, without which neither real thinking nor its linguistic embodiment is possible $[8,190]$. That is why scientific language, as noted by S. Balli, can with great caution be considered a reflection of only the impersonal activity of the mind [1, 144].

Emotionality as a component of cognitive activity is becoming increasingly important. This is due to the increasing complexity of scientific knowledge, with the diversification of ways of obtaining knowledge.

N. Razinkina notes that the combination of conciseness and "impartiality" of logical reasoning with the excitement of emotional and subjective assessment gives scientific work deep conviction. She clarifies: it is worth talking not about the lack of emotional elements, but about the fact that the scientific style "tends to utilize speech figures, devoid of emotionality and expressive colors". Due to the fact that scientific presentation uses logical means of influence and persuasion, there is an opinion that scientific prose is always boring and unoriginal, that the author of a scientific work must accept that his work will be similar to all others written on the same or related topic. This leads to the conclusion that the scientific presentation allows only such well-known paths that cannot create any expressive images. Thus, if scientific prose is fit for purpose, it must be devoid of any emotion. However, the scientific style does not contain any special speech figures; its isolation means only that it is characterized by specific language tools that are organically included in the stylistic resources, as well as some other language tools that are not a necessary part of the language fabric of style $[11,44]$.

Among the reasons for the appearance of emotional elements in the scientific presentation, researchers name first of all the indisputable fact that each style has elements of other styles, because the practical implementers of different styles are the same people who, depending on the circumstances (communication) use a system of language. It is known that historically the scientific style has developed on the basis of art and borrowed many tools and techniques of expression. Over time, scientific language, while developing and crystallizing its style, is increasingly moving away from the language of art $[6,27]$.

The reasons for the violation of the strict logic of scientific presentation also include insufficient processing of language figures necessary for scientific style [11,44]. In general, the specific use of emotional elements in scientific presentation, the appropriate introduction of subjective assessment on the general background of logically constructed term speech - all this allows to preserve the unity of scientific style [11, 52].

Expressiveness and emotionality of scientific presentation are not identical to similar qualities of artistic, journalistic and conversational style, although they have the same name [7, 29]. The difference, as M. Kozhina rightly points out, is both quantitative and, in a sense, qualitative: what is expressive in a scientific text may not be such in an artistic one. In addition to the purpose of communication in a particular area, the specifics of imagery and emotionality is determined by the general linguistic (speech) "background". That is why different styles have different means and ways of expressing expressiveness and emotionality [7, 29].

It is clear that the scientific style differs from other styles by greater objectivity and lack of passion, however, first of all, these texts do have a certain degree of expressiveness, making them much more expressive than business texts [7, 39]; secondly, as already noted, the scientific sphere is also characterized by emotions, and the scientific text - by a certain type of expression. The expressiveness of the scientific style exists due to the cognitive-communicative need: the content of the scientific text becomes more convincing if it is transmitted in the proper form, such as expressive language [7; $8 ; 10]$. R. Budagov notes that accuracy should not lead to monotony $[3,227]$.

Thus, the concepts of emotionality and expressiveness are not the same in different styles of literature. "In the system of each style, the manifestation of emotionality acquires a deep unique embodiment, so that the general laws of style are not violated. The selection of language tools in any style (taking into account figures that are not specific to it) is endowed with a sustained, typical unity, which is manifested in the appropriate organization of language material in connection with the purposes of functional use" [11, 46-47].

The concepts of expressiveness and emotionality, which are manifested differently in different styles of literature, are equally related to the concept of imagery. Imagery is one of the creative means of fictional literature. M. Kozhina notes that in the scientific literature there is no specific feature of artistic style, which is artistic and figurative speech concretization. And this is another confirmation that it is not the use of verbal images, but an artistic and figurative speech concretization that is a truly specific property of artistic speech, not inherent in any other style, and that the concretization of scientific speech belongs to a completely different type $[5,220-221]$. Its main difference is that in science there is a concretization of the concept, and in fiction - the creation of an artistic image. This is only the basis for the difference of concretization in the actual speech (and language) aspect. The difference is that the broad-context concretization of artistic speech is based on figurative meanings of words, in particular on symbolic use, on individual shades, which the authors attach to certain meanings of words [5, 222].

The means of expressiveness of the scientific style include: reinforcing and limiting particles, as well as pronouns, quantitative adverbs: only, extremely, absolutely, etc.; emotionally expressive adjectives: extraordinary, huge, etc.; adjectives and adverbs of the highest 
degree of comparison: the simplest, the largest, the best and others. A peculiar expression of a scientific presentation does not exclude certain imagery. The use of comparisons, analogies, metaphors not only enlivens the presentation, but sometimes is the best way to convey complex, abstract concepts [10, 139-140].

A broad understanding of imagery is a common quality of many researchers. The use of means of imagery in a scientific text, according to M. Kozhina, is fundamentally different from the use of such means in fiction: 1) figurative means, in particular metaphors, in scientific language are mostly only two-dimensional, not multifaceted; 2) metaphors in scientific language have a narrow contextual meaning, they do not have the systemic character that is inherent in artistic language; 3 ) the functions of figurative means in scientific and artistic language are fundamentally different. In a work of art, metaphor is one of the important elements of the general system of images, organically united by a common theme and idea; in scientific language, figurative means perform an auxiliary function - to explain, popularize, specify - and therefore are a kind of instructions that are not organically related to the general speech system [5, 218-223].

Undoubtedly, scientific texts focus on logic, not emotion, but science and technology are not wholly logical, but sometimes also a source of complex emotions. Thus, figurative vocabulary and expressive constructions are used in the scientific literature, but the frequency of use varies depending on the genre, purpose, readership, individuality of the author, the subject of presentation, etc. $[13,165]$.

Figurative means are also common for the style of modern works of those branches of science that are under development. Our analysis of natural and technical texts showed that the most commonly used figurative means are comparisons, analogies and metaphors.

Comparison, according to many scientists, is the most common of figurative means in the scientific field, because it is one of the forms of logical thinking. In trying to figure out a phenomenon of reality, scientists often resort to creating visual images within their imagination, because it is visual images that are the most vivid and expressive. This property of visual images is often used in the second - communicative - stage of cognition to help the reader to form an adequate conceptual picture of the world [10, 141].

Figurative comprehension of reality, as noted by researchers, corresponds to the peculiarities of the human psyche: the basis of each image is a comparison; man learns the new by comparing it with the known. This phenomenon is based on the brain's ability to record old experiences: each new impression makes it necessary to compare it with the already known. That is why in scientific and technical terminology there are a large number of metaphorical terms formed on the basis of comparison: c, Christmas tree maze, helical tooth, sunken finger, etc. $[10,140]$.

The resemblance of one object to another can be conveyed by an adjective that limits the semantics of the noun involved in the matching operation: Гіроскоп-масивне симетричне тіло, яке обертається навколо вільної осі з певною кутовою швидкістю. Свосрідними гіроскопами є планети, снаряди, ротори турбін та інші обертові тіла з масою, яка симетрично розподілена відносно осі обертання $(Ф \mathrm{C}, 64)$ (Gyroscope is a massive symmetrical body that rotates around a free axis at a certain angular velocity. Planets, shells, turbine rotors and other rotating bodies with a mass that is symmetrically distributed about the axis of rotation can also be considered gyroscopes). The aforementioned sentence illustrates, that this method of comparison requires broadening the context (without the first sentence of comparison, only specialists in a narrow field would understand its meaning, which, obviously, was not part of the author's plans).

In modern natural and technical texts, comparisons also function in such grammatical forms as comparative inflection, contracted sentence, comparison of adverbs and adjectives, descriptive comparative constructions, sentences of comparative structure, in which the object of comparison covers the entire predicative part, constructions, built on the principle of figurative analogy $[9,469-470]$.

Comparisons, often grammatically designed as subordinate clauses, are used to explain complex scientific concepts: Бінарний пошук потребуе ключа сортування, який можна порівняти з величинами зі списку елементів, що розтамовані у певній послідовності (КС, 46); Ці розділи пам'яті називають бітовими матричями, тому щзо з ними поводяться так, як ніби вони розташовані один над іншим, хоча вони і займають різні ділянки пам'яті $(\mathrm{KC}, 49)$ (Binary search requires a sorting key that can be compared with the values from the list of elements arranged in a certain sequence; These sections of memory are called bit matrices because they are treated as if they were located one above the other, although they occupy different areas of memory).

In the studied scientific texts there are sentences of comparative structure, in which the object of comparison covers the entire predicative part: Залежно від контексту, аудіовідповідь може бути синонімом для частотної відповіді, маючи на увазі чутливість пристрою до спектра звукових частот (КС, 33); Випадковий доступ - можливість комп'ютера добиратись до певної позичії пам'яті, уникаючи процесу послідовного пошуку з початкової позиції... У людській діяльності еквівалентом иього доступу є можллиість знаходити адресу в адресній книжсиі без послідовного перегляду всіх адрес (КС, 319) (Depending on the context, audio response may be synonymous with frequency response, given the sensitivity of the device to the spectrum of sound frequencies; Random access is the ability of a computer to get to a certain position of memory, avoiding the process of sequential search from the starting position... In human activity, the equivalent of this access is the ability to find an address in the address book without sequentially viewing all addresses).

In modern natural and technical texts, analogies have also been found, for example: Електронна сітка (дисплея на рідких кристалах) може вибірково «вмикати» окрему клітину, яка містить рідкий кристал (КС, 239) (An electronic grid (liquid crystal display) can selectively "switch on" a single cell that 
contains a liquid crystal). The process of triggering a single liquid crystal on a computer screen is really like turning on a device, akin to a light bulb in a dark room.

On the basis of analogy, certain phrases have been established in scientific language, which, although not yet acknowledged as terms, are actively used in texts, for example: ...атоми з недобудованими оболонками (ФС, 16) (...atoms with unfinished shells), whereas the number of electrons on a certain atomic shell is strictly defined; if there are not enough electrons in a certain shell, then the shell seems to be unfinished (analogy with an unfinished building). Another example: силу тяжіння зіставляють із лобовим опором середовища (ФС, 217) (the force of gravity is compared with the frontal resistance of the environment), whereas the environment seems to resist the movement of the body; such resistance is called frontal, because it falls on the front of the moving body (in case of humans it is in front of the forehead).

In comparison with literary texts, scientific texts more often use linguistic metaphors with expressivesemantic and individual-expressive-emotional function $[10,83]$.

For example, in the terminological system of particle physics, the use of metaphors proved to be quite productive: При бомбардуванні алюмінію альфа-частинками утворюсться ізотоп кремнію 3 атомною масою 30 i ше один елемент (ФС, 64); Вторинна електронна емісія - емісія електронів з поверхні тіла у вакуумі під дією бомбардування ї̈ первинними електронами (ФС, 53) (When aluminum is bombarded with alpha particles, a silicon isotope with an atomic mass of 30 and another element is formed; Secondary electron emission is the emission of electrons from the surface of the body in vacuum under the action of bombardment of its primary electrons) - meaning that electrons outside the body (primary electrons), move quickly, "bump" on the body surface ("bombard" it) and therefore separate electrons from atoms, which are called secondary. In the given example the borrowing from financial terminology is also used: the word "emission" has many meanings; in the financial terminology it is used to denote the issuing of money and valuable papers. Obviously, we can draw an analogy with the release of money and the release of electrons from the surface of the body in a vacuum - based on a common comparison, which reflects the movement of something.

Some other purely physical contexts may contain a kind of "military" color: Прискорені електрони в кільчевій камері направляються на об'єкт обстрілу в самій камері (ФС, 26) (Accelerated electrons in the ring chamber are sent to the object of attack in the cell itself). The object of attack is a substance (atoms, nuclei of atoms, etc.) to which the accelerated electrons (or other elementary particles) are directed. Under the influence of electron shocks, the object decomposes into elementary particles. It is the decay processes that are studied with the help of accelerators.

It is easy to trace the comparison of physical phenomena with the phenomena of other spheres, for example, legal: Діставши термодинамічну санкцію на процес, можна на шляху хімічної взаємодії зустріти перешкоду, яка різко сповільняє реакиію (ХГ, 34) (Having obtained a thermodynamic sanction for the process, it is possible to encounter an obstacle in the way of chemical interaction, which heavily slows down the reaction). Speaking of thermodynamic sanction, we mean that according to the laws of thermodynamics, such a process may occur.

There are also nominative metaphors, which are based on simple analogies. For example, commonly used words such as wedge, edge, etc. became the basis for the formation of terms: Крапля проектується паралельним пучком світла на вхідний зрачок об'єктива через клин з кутом при вериині, причому через периу грань клина пучок входить перпендикулярно до неї.. (ОП, 178) (A drop is projected by a parallel beam of light on the input pupil of the lens through a wedge with an angle at the apex, and through the first wedge the beam enters perpendicular to it ...). Wedge is quartz glass, which is made in the shape of a right triangle (resembles the shape of a wedge, which is hammered into a tree to break it).

Conclusions and directions for further research in this area. The analysis of the researched material testifies that figurative means are common for scientific language, whereas scientific expressiveness differs from expressiveness in other styles. If the expressiveness of artistic language lies in the highest degree of imagery, the scientific lies in the provability, concretization of opinions, logic of statements, strengthening the argumentation of the author's reasoning, activating the reader's attention. Expressiveness is one of the characteristic features of scientific presentation and, accordingly, is an integral feature of scientific style texts, so the prospect of further research is to study the pragmatic functions of scientific texts as well as all aspects of communicative factors in scientific and technical texts, both in relation to addressee and how they percept it.

\section{ЛІТЕРАТУРА}

1. Балли Ш. Французская стилистика. Москва : Изд-во иностранной литературы, 1961. 394 с.

2. Бойко Н. I. Українська експресивна лексика : семантичний, лексикографічний і функціональний аспекти : монографія. Ніжин : ТОВ «Вид-во «Аспект-Поліграф», 2005. 552 с.

3. Будагов Р. А. Литературные языки и языковые стили. Москва : Высшая школа, 1967. 376 с.

4. Калмыкова Е. П. О динамике метафоры в научном стиле. НДВШ. Филологические науки. 1974. № 2. С. 83-88.

5. Кожина М. Н. К вопросу о средствах образности в научной речи. Учёные записки Пермского университета. 1966. № 162. С. 210-223.

6. Кожина М. Н. О специфике художественной и научной речи в аспекте функциональной стилистики. Пермь : Пермское книжное изд-во, 1966. 213 с.

7. Кожина М. Н. К проблеме экспрессивности научной речи. Учёные записки Пермского университета. 1971. № 244. Вып. 3. С. 25-41. 
8. Кожина М. Н. О понимании научного стиля и его эволюции в период научно-технического прогресса. Научнотехническая революция и функционирование языков мира : сб. статей. Москва : Наука, 1977. С. 187-198.

9. Мацько Л. І. Порівняння. Украӥнська мова. Енциклопедія. Київ : Українська енциклопедія, 2000. С. 469-470.

10. Непийвода Н. Ф. Мова української науково-технічної літератури (функціонально-стилістичний аспект). Київ : ТОВ «МФА», 1997. $303 \mathrm{c}$.

11. Разинкина Н. М. О преломлении эмоциональных явлений в стиле научной прозы. Особенности языка научной литературы. Москва : Наука, 1965. С. 38-52.

12. Телия В. Н. Механизмы экспрессивной окраски языковых едениц. Человеческий фактор в языке: Языковые механизмы экспрессивности. Москва : Висшая школа, 1991. С. 36-67.

13. Валгина Н. С. Теория текста : учебное пособие. Москва : Логос, 2003. 280 с.

\section{ДЖЕРЕЛА ІЛЮСТРАТИВНОГО МАТЕРІАЛУ}

ФС - Біленко I. І. Фізичний словник. Київ : Вища школа, 1993. 319 с.

КС - Комп’ютерний словник / пер. з англ. В. О. Соловйова. Київ : Україна, 1997. 470 с.

ХГ - Волков С. В., Присяжний В. Д. Холодне горіння. Київ : Наукова думка, 1972. 174 с.

ОПВ - Іващенко Ю. М., Сременко В. Н. Основи прецизійного вимірювання поверхневої енергії розплавів за методом лежачої краплі. Київ : Наукова думка, 1972. 231 с.

\section{REFERENCES}

1. Balli, Sh. (1961). Frantsuzskaya stilistika [Stylistics of the French language]. Moskva: Izdatelstvo inostrannoi literatury [in Russian].

2. Boiko, N. I. (2005). Ukrayinska ekspresyvna leksyka; semantychnyi, leksykografichnyi i funkzionalnyi aspekty [Ukrainian expressive vocabulary: semantic, lexicographic and functional aspects]: monograph. Nizhyn: TOV Vydavnyztvo Aspekt-Poligraph [in Ukrainian].

3. Budagov, R. A. (1967). Litraturnye yazyki I yazykovye stili [Literary languages and language styles]. Moskva: Vysshaia shkola [in Russian].

4. Kalmykova, E. P. (1974). O dinamike metafory v nauchnom stile [On the dynamics of metaphor in scientific style]. NDVSh. Philologicheskie nauki, 2, 83-88 [in Russian].

5. Kozhina, M. N. (1966). K voprosu o sredstvakh jbraznosti v nauchnoy rechi [On the question of imagery means in scientific speech]. Uchenye zapiski Permskogo universiteta, 162, 210-223 [in Russian].

6. Kozhina, M. N. (1966). O spetsifike khudozhestvennoy i nauchnoy rechi v aspekte funrtsionalnoy stilistiki [On the specifics of artistic and scientific speech in the aspect of functional stylistics]. Perm: Permskoe knizhnoe izdatelstvo [in Russian].

7. Kozhina, M. N. (1971). K probleme ekspressivnosti nauchnoy rechi [On the problem of scientific speech expressiveness]. Uchenye zapiski Permskogo universiteta, 244 (3), 25-41 [in Russian].

8. Kozhina, M. N. (1977). O ponimanii nauchnogo stilia i ego evoliutsii v period nauchno-tekhnicheskogo progressa [Understanding scientific style and its evolution during the time of scientific and technical progress]. Scientific and technical revolution and the functioning of the world languages: Digest of articles. Moskva: Nauka, 187-198 [in Russian].

9. Mazko, L. I. (2002). Porivniannia [Comparison]. Ukrainian language. Encyclopedia. Kyiv: Ukrainska Enzyklopediia, 469-470 [in Ukrainian].

10. Nepyivoda, N. F. (1997). Mova ukrainskoi naukovo-tekhnichnoi literature (funktsionalno-stylistychnyi aspect [The language of Ukrainian scientific and technical literature (functional and stylistic aspect)]. Kyiv: TOV "MFA" [in Ukrainian].

11. Razinkina, N. M. (1965). O prelomlenii emotsionalnykh yavlenii v stile nauchnoy prozy [On the refraction of emotional phenomena in the style of scientific prose]. Peculiarities of scientific literature language. Moskva: Nauka, 38-52 [in Russian].

12. Teliia, V. N. (1991). Mechanizmy ekspressivnoy okraski yazykovyh edinits [Mechanisms of language units expressive coloring]. Human factor in language: Language mechanisms of expressiveness. Moskva: Vysshaia shkola, 36-67 [in Russian].

13. Valgina, N. S. (2003). Teoriya teksta: uchebnoe posobie [Text Theory: Coursebook]. Moskva: Logos [in Russian].

\section{SIURCES OF ILLUSTRATIVE MATERIAL}

ФC - Bilenko I. I. Physical Dictionary. Kyiv: Vysshaia shkola, 1993. 319 p.

KC - Computer dictionary / transl. from English by V. O. Soloviova. Kyiv: Ukraina, 1997. 470 p.

$\mathbf{X} \Gamma$ - Volkov S. V. Cold burning / S. V. Volkov, V. D. Prysiazhnyi. Kyiv: Naukova dumka, 1972. 174 p.

OIB - Ivashchenko Yu. M. Fundamentals of precision measurement of melts surface energy by means of sessile drop method / Yu. M. Ivashchenko, V. N. Yeremenko Kyiv: Naukova dumka, 1972. 231 p. 